\title{
Terörizmin Tarihsel Gelişimi Bağlamında Türkiye'nin IŞSiD İle Mücadelesi: Yabancı Terörist Savaşçılar Örneği
}

\section{Dr. Şeref Çetinkaya ${ }^{{ }^{*}}$}

Geliş tarihi: 06.12.2019

Kabul tarihi: 06.01.2020

\section{Atuf bilgisi:}

IBAD Sosyal Bilimler Dergisi

Sayı: 6

Sayfa: $145-160$

Yıl: 2020 Dönem: Kıs

This article was checked by iThenticate. Similarity Index $02 \%$

Bu makalede araştırma ve yayın etiğine uyulmuştur.

\footnotetext{
1 İstanbul Emniyet Müdürlüğü, Türkive, seref_c@hotmail.com,

ORCID ID 0000-0002-6446-2322
}

* Sorumlu yazar öz

Terörizm, son yıllarda uluslararası ilişkileri etkileyen en önemli konulardan biri haline gelmiştir. Özellikle Orta Doğu'daki istikrarsızlık ve kaos durumu, bölgedeki terör örgütlerinin büyümesine yol açmıştır. IŞīD de bölgedeki bu durumdan beslenerek büyüyen terör örgütlerinden biridir ve çektiği infaz görüntülerini internet üzerinden yayınlayarak tüm dünya tarafindan tanınır hale gelmiştir. Selefi-cihadist ideolojiyle hareket eden IŞiD, son yıllarda birçok ülkede gerçekleştirdiği sansasyonel eylemlerle uluslararası terörizmin ulaştığı noktayı göstermektedir. IȘíD, dünyanın birçok ülkesinde gerçekleştirdiği eylemlerde "Yabancı Terörist Savaşçı" (YTS) adı verilen kişileri kullanmaktadır. Bir kısım YTS'ler kendi ülkelerinde kalarak IȘiD'e bu ülkelerde destek vermekte, diğer kısım YTS'ler ise Suriye ve Irak'taki çatışma bölgelerine giderek IŞīD saflarında mücadele etmek suretiyle desteklerini göstermektedir. Dünyanın birçok ülkesi ve Türkiye'nin de katılımıyla YTS'lere karşı mücadele edilmektedir. Bu çalışmanın temel amacı YTS'lerin IŞiD içindeki rolünü belirlemek ve Türkiye'nin YTS'lere karşı verdiği çok boyutlu mücadeleyi irdelemeye çalışmaktır. Bunun için Türkiye Cumhuriyeti İç İşleri Bakanlığı'ndan elde edilen resmi veriler kullanılmıştır.

Anahtar Kelimeler: Terörizm, Yabancı Terörist Savașçı, IŞID, Türkiye, Terör Örgütü. 


\section{Turkey's Fight Against ISIS In The Context Of The Historical Development Of Terrorism: Example of Foreign Terrorist Fighters}

\section{Ph. D. Şeref Çetinkaya ${ }^{1^{*}}$}

First received: 06.12.2019

Accepted: 06.01.2020

\section{Citation:}

IBAD Journal of Social Sciences

Issue: 6

Pages: $145-160$

Year: 2020

Session: Winter

This article was checked by iThenticate. Similarity Index $02 \%$

\footnotetext{
1 Istanbul Police Department, Turkey, seref_c@hotmail.com,

ORCID ID 0000-0002-6446-2322
}

* Corresponding Author

\begin{abstract}
Terrorism has become one of the most important issues affecting international relations in recent years. The unstability and chaos in the Middle East, in particular, has led to the growth of terrorist organizations in the region. ISIS is only one of the terrorist organizations which has established its presence in the region by use of this chaotic situation and has become known by the whole world through the execution videos publishing on the internet. ISIS, acting with its Salafist-jihadist ideology, has been showing the reached point of international terrorism by making sensational actions in many countries in recent years. ISIS has used the people called "Foreign Terrorist Fighter" (FTF) in terrorist acts in many countries. Some of the FTFs remain in their own countries and support ISIS in these countries. The other part of FTFs shows their supports by crossing to the conflict zones in Syria and Iraq and by fighting in the ISIS ranks. With the participation of Turkey and many other countries, there is a fight against FTFs. The main purpose of this study is to determine the role of the FTFs in ISIS and to try to analyze Turkey's multidimensional fight against FTFs. Official data declared from the Ministry of Interior of the Republic of Turkey were used in the analyses.
\end{abstract}

Key Words: Terrorism, Foreign Terrorist Fighter, ISIS, Turkey, Terrorist Organization 


\section{INTRODUCTION}

There is no consensus on the definition of the concept of terrorism; however, some elements such as fear, violence and ideology are mentioned in common terms. When looked at the historical background of terrorism, it is possible to go back up to two thousand years ago (Kurum, 2015). As such, terrorist organizations that have gone through various stages from two thousand years ago to the present day are now making attacks with different ways and methods and have their names mentioned in wide geographical areas.

When the advances in science and technology, which have started towards the end of the $20^{\text {th }}$ Century and have continued rapidly until our present day, are combined with the developments brought about by the phenomenon of globalization, a very different and complex type of terrorist organization structure emerges. Innovations in communication systems and the increase in the use of the internet have strengthened the security forces' hands on many issues, and have also led the terrorist organizations use these improvements, as well.

The development of terrorist organizations in such different dimensions has made it difficult to achieve success only by means of the security forces in terms of fighting terrorism. Political, economic, cultural and social aspects of terrorism should also be addressed. The situation is no different for ISIS (Islamic State of Iraq and Syria), which has emerged in this atmosphere and has been described as one of the bloodiest terrorist organizations of all time by the world public opinion.

When the ideology of ISIS is examined, it is seen that concepts such as Kharijism and Salafism come to the fore and the idea of jihad is built in the light of these concepts. When evaluated in the historical process, the origins of ISIS are based on Al Qaeda, which has made a name for itself during and after the Afghanistan war. In time, it left Al Qaeda by taking the name of Islamic State of Iraq and Syria.

ISIS has become one of the most discussed terrorist organizations in recent years. ISIS came to the forefront with its videos prepared with professional shots published on social media and the capacity to act in different geographies of the World. ISIS has been considered as a serious threat in the international arena, especially in Western countries, and then, in time, the process leading to the establishment of an international coalition against ISIS has started.

Turkey is one of the leading countries in the fight against ISIS. Turkey has already been fighting terrorism for many years, and ISIS has been added to the terrorist organization list. Turkey has entered into a multi-dimensional fight against ISIS. Among the reasons for this, ISIS geographically located right next to the border with Turkey and the presence of foreign terrorist fighters (FTFs) who want to join the organization by passing through Turkey can be expressed.

In this study, the position of foreign terrorist fighters (FTFs) in ISIS will be examined and then Turkey's fight methods against these fighters will be explained. The hypothesis of the study is as follows; Turkey fights against FTFs in a multi-dimensional scale. In conclusion, the accuracy of the hypothesis will be evaluated within the framework of the findings.

As ISIS and foreign terrorist fighters are an ongoing problem, they require researchers to tackle data constraints. Currently, the difficulty of entering the area of conflict prevents data collection. In this study, official data announced by the Ministry of Interior will be used.

\section{TERROR AND TERRORISM CONCEPTS}

The concept of terror is derived from the Latin word 'terrere' and means "shudder or cause it, horror, unpredictable danger" (Wilkinson, 1986, p. 3). Terror is a state of great fear that is created by a group or faction through the use of violence, in an organized way, to seek power (Taner, 2000, p. 93). The 
concept of terror was included in the October issue of the Dictionary of the French Academy (Dictionnaire de I'Aca damie Francais) in 1789 and was first described as the "terror regime" (Demir, 2008, p. 74). The main purpose of this usage in the Academy Dictionary is to intimidate the opposing movements against the new power that established after the French Revolution of 1789 and to strengthen the place of power (Hoffman, 2006, p. 3). Also, the concepts of intimidation and suppression are used instead of terror (Çağlar, 1997, p. 119). However, the scale of intimidation and suppression is quite large at both the individual and community levels (Özerkmen, 2004, p. 249).

Thornton, who addressed the terror concept academically for the first time, defined terror as "symbolic activities that aimed influencing and manipulating political behavior through ordinary ways and methods". Thornton stated that terrorist activities are used to achieve political goals (Thornton, 1964, p. 71). As it is seen, there is no single definition regarding the concept of terrorism. However, in all definitions, the element of violence is encountered.

The concept of terrorism appears to be derived from terror. The words that end with "ism" is usually associated with a doctrine, whereas the concept of terrorism mostly refers to the strategy and discourse dimension of terrorist acts. In other words, the concept of terrorism includes the philosophical, political, sociological and legal aspects of the action (Urhal, 2009, p. 262). Terrorism is a concept that involves the planned and organized illegal activities of a group in order to achieve its own ideological, religious or political aims (Bergesen and Han, 2005, p. 134; Tavares, 2004, p. 1041).

Wilkinson, one of the leading researchers on the subject of terrorism, expresses that terrorism can occur with a single act or a random mass violence movement; and according to him, such acts of terrorism are generally not carried out systematically. Therefore, a series of coincidental actions should not be referred to as terrorism (Wilkinson, 1986, p. 17-18).

The common points regarding the definition and scope of terrorism may be listed as follows (Caşin, 2008, p. 102):

Existence of violent acts,

Existence of political and ideological elements,

Organized terror,

Existence of brutal, savage practices,

The public's feeling of despair in the face of terrorist activities and breaking the sense of trust,

Advertising in order to make a name in national and international arena and making it a part of violence,

$>\quad$ Presence of secretly prepared plans and strategies,

Using advanced weapons at the highest level by making the most of the opportunities provided by technology.

\section{A BRIEF HISTORY OF TERRORISM}

One of the oldest groups considered to act systematically on terrorism is the Sicarii (A.D. 66-73). The Sicarii were a splinter group of the Jewish Zealots who, in the decades preceding Jerusalem's destruction in (A.D.) 70, strongly opposed the Roman occupation of Judea and attempted to expel them and their sympathizers from the area (Goodman, 2008, p. 407). The Sicarii carried small daggers called sicae, concealed in their cloaks. At public gatherings, they pulled out these daggers to attack 
Romans and Hebrew Roman sympathizers alike, blending into the crowd after the deed to escape detection (Christian, 2004).

The Sicarii resorted to different methods in terms of terrorism. In addition to spreading fear through the assassinations committed by the sicae among the crowds, they also organized attacks on tax buildings in order to get the support of the people suffering from heavy taxes (Chaliand and Blin, 2007, p. 55-56).

Another organization that comes to mind when the concept of terrorism is mentioned is Assassins. They were the Nizari Ismailis in the mountains of Persia and Syria between 1090-1272. The name was not used by the Nizaris themselves, but was given to them by their opponents in Syria. Nizarism formed in the late $11^{\text {th }}$ Century after a split within Ismailism. Based on texts from Alamut, their grand master Hassan Sabbah called his disciples Asāsiyyūn, but some foreign travelers like Marco Polo misunderstood the name as deriving from the term hashish (Burman, 1987, p. 70; Lewis, 1967, p. 30). The strategies of the Assassins actions are based on the systematic attacks of small groups. In their assassinations, they mostly targeted the leading statesmen of the period (Hoffman, 2006, p. 84). The withdrawal of the Assassins from the historical scene took place with the occupation of the Alamut Fortress in 1272 by the Mongols (Laqueur, 1999, p. 8-9).

The emergence of terrorism in the modern sense coincides with the period after the French Revolution. Robespierre, one of the leaders of the Revolution, commissioned special military units to suppress riots against the new regime and executed them by guillotine. The reason for using guillotine is to increase the fear on the public and to take precautions against other potential rebels. For this reason, this period was called as "terror regime". In other words, this period of terror was designed with the support of the state in order to maintain public order (Kartal, 2018, p. 44).

In 1879, a group called od Narodnaya Volya" (People's Will) was established in Russia and aimed to fight against Tsarist Russia. According to this group, the use of terrorism was considered legitimate in order to raise public awareness. Narodnaya Volya stated that unarmed propaganda methods did not work, and that a systematic and continuous terrorist movement could be revolutionized (Rapoport, 2003, p. 38). Narodnaya Volya succeeded in the assassination of the Russian Tsar in 1881. Although this event was not enough for the uprising of the people for that period, it was described as the first step of the subsequent process of the 1917 Bolshevik Revolution (Ternon, 2007, p. 150).

The revolutionary character of terrorism lasted until the World War I (Hoffman, 2006, p. 11). However, the assassination of the Archduke of Austria on June 26, 1914, which was said to have fired the wick of World War I, and the assassination actions against high-level state administrators in the ongoing process, are indicators of the end of anarchist terrorism and the emergence of nationalist terrorism (Chailand and Blin, 2007, p. 177).

After World War I, especially after 1930, there was a difference in the users of terrorism. In this period, totalitarian and dictatorial leaders, who held power, used terrorism for the people in their own country. The Fascist Party in Italy, the National Socialists in Germany, and Stalin in Russia used terrorism as a means to control and prevent all movements and oppositions in the country (Hoffman, 2006, p. 14).

After World War II, the international structure became bipolar as the US and the Soviet Union. Alliances made during this period (such as NATO, Warsaw Pact) prevented possible conflicts between the countries, and instead, it was started to be done through terrorist organizations about the target country. States did not attack each other, but instead of this, a third party was used as a "proxy war" (Kartal, 2018, p. 45). 
During the US intervention in Vietnam, an organization called "Vietkong" emerged which acted with terrorist acts. The US, which had modern weapons, was not able to act in the face of the actions of this organization and the weakness of the West in this area became questionable (Rapoport, 2003, p. 41). Later in this period, the proliferation of ethnic nationalist groups, which emerged in addition to revolutionary terrorism, and the emergence of new anti-colonial ideological organizations, accelerated the spread of terrorism. In this sense, organizations such as PLO, ETA, ASALA, IRA used terrorism as a means to attract the attention of the world public (Hoffman, 2006, p. 16).

In 1983, the terrorist organization called Hezbollah killed 241 American soldiers by using suicide bombers, in Beirut. After this action, Western countries withdrew their troops in the region. This action is important for the psychological impact of terrorism to be so effective even on strong states (Chailand and Blin, 2007, p. 222).

In 1979, when the Shah regime was overthrown in Iran and the Islamic Republic was established, it was important in terms of showing that religion could be an important political tool. In addition, during the Soviet invasion of Afghanistan, Salafist-Jihad understanding succeeded against Soviets and this revealed the importance of religion in politics (Rapoport, 2006, p. 13). In this process, as a result of the jihad understanding and the Sunni resistance movement that was effective in Afghanistan, a terrorist organization called Al Qaeda emerged. In order to contribute to this resistance, people from many different geographical areas of the world came to Afghanistan and so Al Qaeda started to have a serious impact. Following the Soviets' withdrawal from Afghanistan, some of those involved in the resistance remained in Al-Qaeda, while others returned to their countries and continued to maintain relations with Al-Qaeda (Rapoport, 2006, p. 15). Al Qaeda has now become a global terrorist organization which has organization elements in many countries of the world. As a result, a new terrorist organization emerged with $\mathrm{Al}$ Qaeda (Cronin, 2010, p. 44).

The attacks on the Twin Towers in the United States on September 11, 2001 are very important in terms of showing the point reached by terrorism. Terrorism, which operates within certain limits, has become an identity that can now reach beyond borders. As a result of these actions, terrorism has gained a global dimension and has become widespread rapidly throughout the world (Kartal, 2018, p. 52).

Today, ISIS, which is one of the most brutal terrorist organizations, declared Caliphate on June 28, 2014; and declared that Abu Bakr al-Baghdadi was chosen as caliph. After that, Baghdadi invited Muslims from all over the world to the so-called Islamic State. As a result, many foreign terrorist fighters from different regions tried to reach the ISIS-dominated region. The fact that this region is in Turkey's border led to foreign terrorist fighters want to travel through Turkey. Therefore, it was necessary to prevent foreign terrorist fighters from entering the conflict zones. At this point, Turkey has had a multi-dimensional strategy for fighting this situation.

\section{ISIS'S PERSONNEL SOURCE: FOREIGN TERRORIST FIGHTERS}

Foreign terrorist fighters (FTFs) have been providing a large part of the personnel source of terrorist organizations in the Middle East for many years. In this sense, the issue of FTF, which threatens the security of the region and even international security, has come up again with ISIS after 2014. The increasing number of FTFs who wanted to move to conflict zones caused this issue to become an international problem (Dede, 2018, p. 37).

When the literature on the subject of FTFs is examined, it is noteworthy that the resources are limited and the definitions made on the systematic basis of the West are based on anti-Islam. This may be a problem for the objective handling of the issue. It is seen that the Western world generally deals with FTFs in terms of problems that may arise when FTFs return to their home countries (Bingöl, 2016, p. 1). Apparently, it is also difficult to agree on the definitions of FTF. 
The first use of the FTF concept in the academic field took place during the ISIS invasion of Iraq. The Western perspective used the term FTF mainly for radicals from Europe who joined Salafist-jihadist organizations. The concept that is used for the militants involved in the 2009 Ghana War was used to define radical terrorist groups over time (Istanbullu, 2017, p. 55).

The issue of FTF in 2014 - as mentioned earlier - seemed to be seriously debated by the international community. The propaganda methods of ISIS and the increase of the occupied territories can be counted among the developments that open the door to thousands of FTFs who want to come to conflict zones from different geographical areas of the world. The increasingly unbearable situation has prompted the United Nations to mobilize; and it became one of the issues to be addressed at the General Assembly on 24 September 2014. Another important factor in the European countries' focus on FTF was the terrorist attacks in Paris on January 7, 2015. The fact that the Kouachi brothers, who were described as suspects of the act known as the Charlie Hebdo attack, were French citizens and made propaganda to increase the participation of FTFs in conflict zones, recalled the seriousness of the FTF issue among Western countries (Kardaş and Özdemir, 2015, p. 9). It is known that there are still FTFs from more than 80 countries in conflict zones.

Lewis examined the planning of ISIS's rise and its implementation through four stages as follows (Lewis, 2013, p. 7):

\begin{abstract}
First stage is "Breaking the Walls". According to this, the ISIS terrorist organization made suicide attacks and prison raids between July 2012 and September 2013. During the same period, ISIS raided four prisons. Approximately one hundred prisoners were kidnapped from the Tasfirat Prison in Tikrit in September 2012 (Lewis, 2013, p. 13-15). In July 2013, ISIS attacked Abu Ghraib and Thaci Prisons near Baghdad at the same time, and many prisoners escaped. The point that draws attention rather than the numerical equivalent of the prisoners who were kidnapped from prisons is that there were leading cadres among the escaping prisoners. In addition, these actions are important in pointing out how good ISIS's armament, intelligence and coordination skills are (Agar, 2015, p. 299-300). Another allegation regarding the prisoners is that the kidnappers included Al-Qaeda terrorists and former senior Ba'ath officers and later assumed important duties within ISIS (Güler and Özdemir, 2018, p. 474475).
\end{abstract}

$>\quad$ In the second stage, ISIS launched attacks on the region between the Barzani administration and the Iraqi Central Government; and tried to exploit the tension between these two administrations (Lewis, 2013, p. 16).

$>\quad$ In the third stage, there are actions aimed at sympathy with ISIS by Sunnis. Especially during the February-May period of 2013, ISIS, which carried out bomb attacks on Baghdad and the surrounding Shiite regions, accelerated its actions targeting Iraqi security forces in this period.

In the fourth stage, after mid-May 2013, ISIS continued its attacks on Baghdad and its surroundings targeting Shiites (Lewis, 2013, p. 17). As a result of these ISIS attacks on Shiite targets, it can be said that new armed groups of Shiites emerged in the region (Bektaş and Gündoğdu, 2019, p. 33).

Due to the growing ISIS, Turkey increased its precautions against ISIS. In this section, the policies implemented for this purpose will be briefly mentioned.

\title{
4. TURKEY'S FIGHT AGAINST ISIS: IMPLEMENTED POLICIES
}

Turkey is a country that has been fighting organized terrorism for nearly forty years. The terrorist attacks, which were not considered enough in the early times, became more complex over time. In this 
period, the fight against terrorism was evaluated according to the number of terrorists killed. However, focusing on this point has caused problems and even some practices that went out of law have started. Today, the concept of fighting terrorism has been removed from this context; and a multi-dimensional counter-terrorism content has been created. Instead of only the perception of the fight of the security forces, a new understanding has been introduced in which civilian areas are also engaged (Bilgesam, 2017). Turkey has been fighting terrorism in the framework of this new approach.

When Turkey's fight against ISIS whose name has been mentioned frequently in recent years and which has the capacity to act on an international scale, is examined, it can be said that Turkey is much higher compared to other countries the possibility of exposure to ISIS action. Therefore, Turkey continues to fight against ISIS on two levels. This fight, which is carried out at national and international levels, is based on the strategy of preventive fight against ISIS at national level and the strategy of providing military and political support to the international coalition against ISIS at international level. Turkey makes threat perception across the two points against ISIS. These two points are; FTFs and violation of border security due to geographically close proximity (Yeşiltaş et al., 2016, p. 45).

One of the important steps in ISIS's policy of recruiting personnel is to pass the personnel to the conflict areas in Syria in particular. For the FTFs who want to join the organization, Turkey is very important as a transition route. This means a significant threat to Turkey. The deployment of ISIS in Syria and Iraq has given the ability to engage in terrorist attacks against neighboring countries. Therefore, this situation consists of a new threat area in terms of Turkey.

States or international organizations publish lists of terrorist organizations at various times. However, the disagreement over the concept of terrorist organization is also experienced in relation to these lists. In some countries "the terrorist organization" is clearly defined in the Penal Code, while in some countries only acts which are considered a terrorist offense are mentioned. In this sense, different practices stand out in terms of declaring ISIS as a terrorist organization. Turkey announced ISIS as a terrorist organization with the Council of Ministers' decision on 30.09.2013 and with the number 5428, and renewed this decree of the Council of Ministers on 21.05.2014. ISIS was accepted as a terrorist organization with two different decisions taken in 2014 by Nigde and Bayburt Assize Courts and was thus included in the judicial decisions (Ministry of Interior, 2017, p. 16).

In Turkey's fight against ISIS, the issue of FTF, the measures taken against ISIS's financial resources and the support given to the international coalition formed against ISIS stand out. The objectives of this fight can be summarized as follows (Yeşiltaş et al., 2016, p. 52):

$>\quad$ Preventing border crossings of foreign terrorist fighters (FTFs),

$>\quad$ Cutting the financial and economic resources of ISIS,

$>\quad$ Supporting military operations,

$>\quad$ Responding to the ideological propaganda that ISIS tries to spread by using written and visual media and developing a counter discourse...

\section{TURKEY'S FIGHT AGAINST FOREIGN TERRORIST FIGHTERS (FTFs)}

Turkey has a long border line with conflict zones in Syria and Iraq. For this reason, Turkey has become an important route for FTFs who want to switch from different places to these conflict areas.

FTFs usually use the airports in Istanbul and Antalya, the highways in Greece, Bulgaria, Georgia, the ports in Izmir and Mersin and try transit roads. FTFs, who come to Turkey by these ways, go to close to the border region by provinces (Gaziantep, Hatay, Sanliurfa like) by using airline or highway. They 
wait for the right time to move from these provinces to conflict areas and try to pass illegally (Ministry of Interior, 2017, p. 52).

Turkey's strategy against FTFs consists of nested four layers. These are prevention in the origin country, prevention at borders, prevention at homeland and prevention at entry and return to Syria (see Figure-1)

Figure-1: Layers of Turkey's Strategy for Fighting FTFs

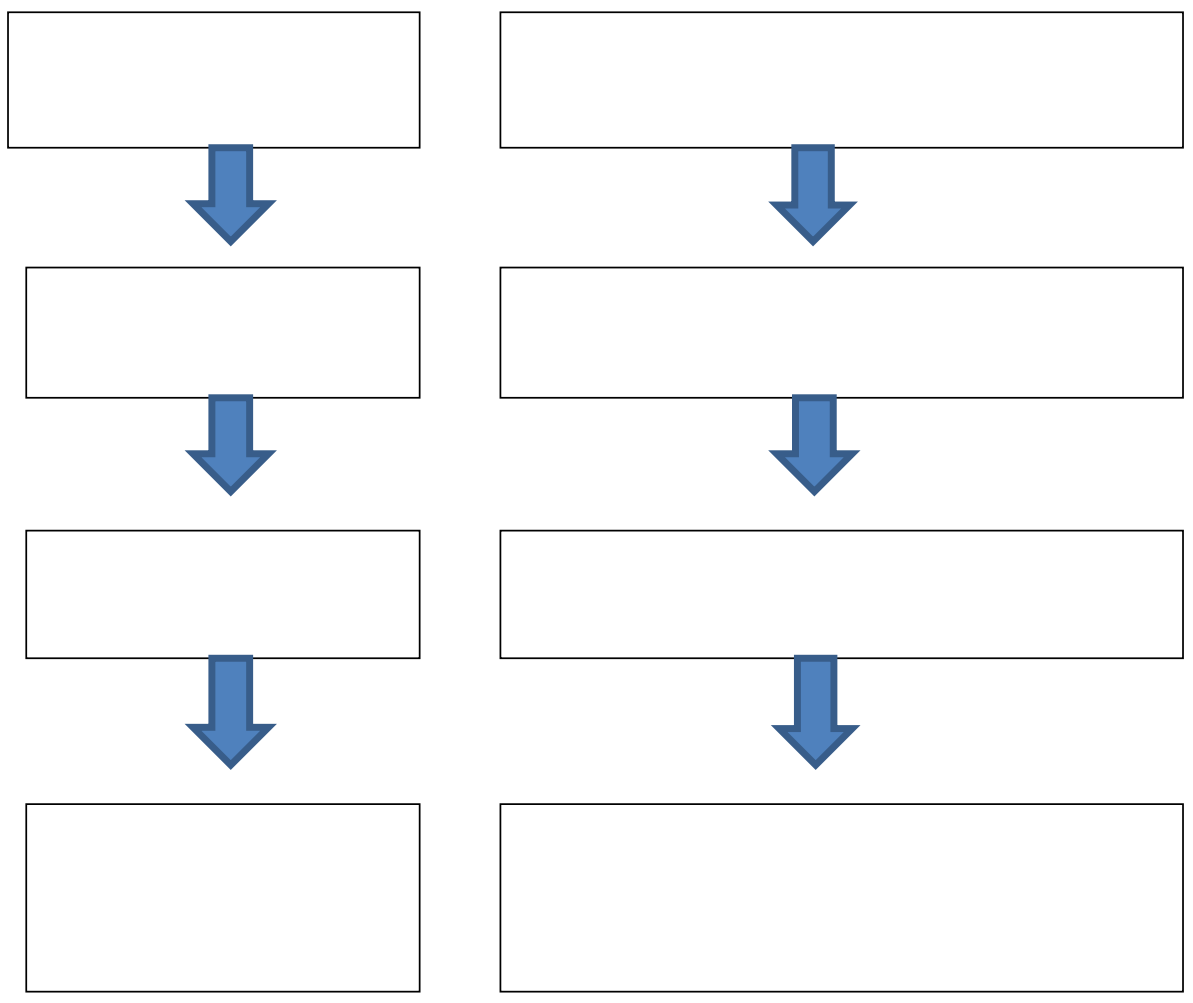

Source: Yeşiltaş et al., p. 52.

\subsection{Prevention in the Origin Country}

FTF subject is very important for Turkey. Thousands of people who want to join ISIS from different regions of the world have been trying to use the geography of Turkey to go to conflict areas. In this sense, Turkey is under serious threat. For this reason, Turkey gives great importance to take measures in terms of FTFs in the fight against ISIS (Özer and Kayk1, 2015). However, it is obvious that only the measures that will be taken at the border of Turkey are not adequate. Success in FTF issue will be possible through international cooperation. Cooperation, especially in the field of intelligence, is vital.

Preventive measures need to be taken by preventing the people who have the potential to go to conflict zones from leaving the country of origin. Considering the fact that FTFs are trying to travel into conflict zones by using false documents and illegal ways, it is clear how important the international cooperation and the measures to be taken in the origin countries (Ministry of Interior, 2017, p. 52).

The case study would be useful to understand the issue of prevention in the origin country. Ibrahim El Bekrewi is one of the perpetrators of the bombing that took place at the Zaventem Airport and 
Maalbek metro station in Brussels on 22 March 2016, resulting in the deaths of 34 people (Milliyet, 2016). Ibrahim al Bekrewi, who was one of the responsible people of these attacks, entered Turkey on June 11, 2015 and was identified three days later in Gaziantep during routine checks carried out by police. Bekrewi was then sent back to the Netherlands from Istanbul Atatürk Airport on 14 July 2015. This information has emerged as a result of the research conducted after the Brussels attacks (Yeşiltaş et al., 2016, p. 54). The cause of this person to be sent to the Netherlands from Turkey was "police suspicion that this person could be foreign terrorist fighter". The Dutch and Belgian authorities were also informed on this issue by giving a note. El Bekrewi also tried to re-enter Turkey by using Antalya Airport on August 11, 2015 but was deported second time by Turkish officials on August 25 (Hürriyet, 2016).

\subsection{Prevention at Borders}

Turkey has considered ISIS as a terrorist organization with the decision of the Council of Ministers in 2013 and thereafter has determined strategies in this direction. At the same time, in 2014 and 2015, the United Nations Security Council took measures against foreign terrorist fighters with resolutions 2170, 2178 and 2199. Within the framework of these decisions, Turkey is cooperating at international level in the fight against the FTFs. Turkey has also presented some implementations in terms of FTFs as part of the urgent measures of the United Nations Global Forum on Counter Terrorism. These implements include the travels of FTFs, legal arrangements related to FTFs, active fight against terrorism and prevention of FTFs' financial resources (United Nations Security Council Resolution, 2014).

One of the implements that is related to FTFs who Turkey fights with is preventing illegal crossings from borders to the conflict zones. Because of this, in 2014, "Risk Analysis Groups" consisting of Intelligence, Counterterrorism and Smuggling units were established within General Directorate of Police at 66 locations in 33 provinces to serve in air and land border gates and bus stations. Risk analysis groups try to determine the people related to ISIS or not, by asking them why they are in Turkey, where they came from, how many days would they stay in Turkey and if they had return ticket. It is possible by this determination that the person is allowed to enter Turkey or is returned to the country of origin.

These risk analysis groups, from the day they were established until June 7, 2017; has checked 17.500 suspicious foreigners wishing to enter Turkey and made exclusive interviews with 10.232 people; and about 4550 of them were deported. Looking at the data of the General Directorate of Migration Management dated 16 June 2017; since 2011 to 2017, there were 4.957 foreign nationals who were caught and deported when they wanted to go to conflict zones. Similarly, 53.781 people from 146 countries have been banned from entry to Turkey as they were linked to terrorism or conflict zones (Ministry of Interior, 2017, p. 55-56).

Table-1: Distribution of Deported Suspects by Country (top 10 countries)

\begin{tabular}{|l|c|}
\hline \multicolumn{1}{|c|}{ NATIONALITY } & TOTAL \\
\hline RUSSIAN & 804 \\
\hline INDONESIAN & 435 \\
\hline TAJIKISTAN & 308 \\
\hline
\end{tabular}


Turkey's Fight Against ISIS In The Context Of The Historical Development Of Terrorism: Example of Foreign Terrorist Fighters

\begin{tabular}{|c|c|}
\hline IRAQI & 278 \\
\hline FRENCH & 254 \\
\hline AZERBAIJANI & 252 \\
\hline MOROCCAN & 183 \\
\hline EGYPTIAN & 150 \\
\hline SAUDI ARABIA & 141 \\
\hline GERMAN & 133 \\
\hline OTHERS & 2.019 \\
\hline TOTAL & 4.957 \\
\hline
\end{tabular}

Source: Ministry of Interior, p. 57.

Table-2: Distribution of Banned from Entry Suspects by Country (top 10 countries)

\begin{tabular}{|l|c|}
\hline \multicolumn{1}{|c|}{ NATIONALITY } & TOTAL \\
\hline SAUDI ARABIA & 7.523 \\
\hline TUNUSIAN & 4.605 \\
\hline RUSSIAN & 4.128 \\
\hline MOROCCAN & 2.831 \\
\hline TAJIKISTAN & 2.651 \\
\hline FRENCH & 2.622 \\
\hline KAZAKHSTANI & 2.085 \\
\hline AZERBAIJANI & 1.914 \\
\hline
\end{tabular}




\begin{tabular}{|l|c|}
\hline BELGIAN & 1.519 \\
\hline OTHERS & 22.226 \\
\hline TOTAL & $\mathbf{5 3 . 7 8 1}$ \\
\hline
\end{tabular}

Source: Ministry of Interior, p. 58.

\subsection{Prevention in Homeland}

Turkey has accelerated its operations against ISIS within the country after June 2015. Increased operations have led to an increase in custody and arrests. The operations were carried out on a large scale, with pre-action prevention and post-action capture.

Table-3: Domestic Operations Figures for ISIS (Custody and Arrests: 2011-2017)

\begin{tabular}{|l|c|c|}
\hline \multicolumn{1}{|c|}{ POLICE + GENDARME } & In 2017 & Between 2011-2017 TOTAL \\
\hline CUSTODY & 3.515 & 9.350 \\
& $(1.540$ Foreigner $)$ & (3.840 Foreigner) \\
ARREST & 1.428 & 3.069 \\
\hline
\end{tabular}

As in the Table-3, 9.350 FTFs were taken into custody, and 3.840 of them were foreigners and 3.069 FTFs were arrested, and 1.337 of the foreigners between 2011-2017 in Turkey. In addition, 763 people were taken into custody at the same time as a result of the ISIS operation in 29 provinces on 5 February 2017.

\subsection{Prevention at Entry to Syria and Return from Syria}

In border areas, the patrol services were increased to prevent illegal passing of FTFs from conflict zones to Turkey. In addition, efforts were made to establish physical barriers and technology-based security systems to ensure security along the border. Then, a $32-\mathrm{km}$ wall was built at the HatayReyhanl1 / Syrian border. The number of soldiers deployed along the Syrian border line was increased. The number of soldiers serving along this border reached 30 per cent of the Turkish Land Forces Command's troops involved in all boundary lines (Hürriyet, 2015). Through these measures, the entry and exit of especially FTFs to Turkey can be prevented. Turkey has achieved important results thanks to the measures that were taken at crossing border illegally from Turkey to Syria or from Syria to Turkey. While the number of irregular migrants who managed to cross to the Greek Islands before March 2015 was around 7.000, the number of irregular migrants decreased to around 40 thanks to the measures. 574.000 irregular migrants were caught, and 162.000 of these were at seas between 2011 and 2017, and 15.155 organizers who organized these transitions were also caught in this process. Also, with the help of "Turkey Passenger Information System" that was established by the General Directorate of Migration Administration, the API / PNR information of the passengers who wanted to come to Turkey was provided. In this way, the FTFs were prevented from entering Turkey (Ministry of Interior, 2017, p. 59). 


\section{CONCLUSION}

The issue of terrorism is one of the most important problems facing states today. Terrorism, which affects each of the military, political, social, economic and cultural areas at different levels, does not seem to be a problem that will be solved in the short term.

It can be said that ISIS has become one of the most debated terrorist organizations in the world in recent years in the context of international terrorism. The ideological background of ISIS is based on the understanding of Salafism and jihad. Salafism is a movement of thought that refuses interpretation and explanation. This movement of thought rejects logical interpretations and reasoning by stating that logic and mind in Islam came to life under the influence of the Greek thought system. This movement, in the sense of understanding the religion, takes model only the period when the Islamic religion came first.

It can be said that ISIS is quite successful in finding new personnel to fight in its ranks. The fact that participation taking place from many different geographical areas of the world to ISIS can be an indication of this situation. ISIS is using the developing technology and communication systems well. In some periods, ISIS scares the people who do not believe in itself and gives moral to the sympathizers in many parts of the world by serving execution videos to the whole world via the internet.

The members of the organization, who is fighting for ISIS by going to conflict zones, are called "Foreign Terrorist Fighters" (FTFs). Looking at the current position of ISIS, it is seen that there is participation of FTFs from many countries of the world. This indicates how effective the organization is in terms of international terrorism.

Turkey has entered into quite a hard fight against FTFs, which are the most important human resources of ISIS. Turkey is an important route line for the FTFs who want to go to conflict zones. Important factors promoting the use of this route are the length of the land border of Turkey with Syria and Iraq and ISIS is located right next to the border of Turkey. Therefore, Turkey is in a wide variety of work in order to prevent the use of this route.

"Risk Analysis Groups" consisting of relevant police units have been established at intercity bus stations, airports and border gates to fight against FTFs. The task of the risk analysis groups is to establish the necessary transactions by interviewing the suspected individuals who may be FTF. In addition, by contacting the countries where FTFs are citizens and making necessary warnings about not allowing these people leave their country. Another point in the fight against FTFs has been directed towards ISIS members in Turkey. Thousands of FTFs were taken into custody and/or were arrested as a result of the operations. At the same time, Turkey has set up physical barriers and technological camera systems along the border in order to ensure the security of its borders. In this way, Turkey prevents the return of FTFs from conflict zones or to go to the conflict zones. As a result, it can be expressed that Turkey has been fighting against FTFs in a multi-dimensional manner by prevention in the origin country, prevention at borders, prevention in homeland, prevention at entry Syria and return from Syria.

\section{REFERENCES}

Ağar, A. (2015). IŞİD ve Irak. İstanbul: Remzi Kitabevi.

Bektaş, M. H. M. \& Gündoğdu, A. Y. (2019). IşİD'in hibrit savaş stratejileri: hibrit savaş konsepti perspektifinden analizi. International Journal of Politics and Security, 1(1), 25-56. 
Bergesen, A. J. \& Han, Y. (2005). New directions for terrorism research. International Journal of Comparative Sociology, 46, 133-153.

Bilgesam. (2019). Terörle mücadele stratejisi. Retrieved from http://www.bilgesam.org/Images/Haberler/Haberler Diger/terorlemucadeleozet.pdf on June 1, 2019.

Bingöl, O. (2016). Suriye iç savaşında yabancı savaşçılar. Merkez Strateji Enstitüsü Raporu, Rapor No: 13, 1-21.

Burman, E. (1987). The assassins - holy killers of Islam, Wellingborough. United Kingdom: Crucible.

Caşin, M. H. (2008). Uluslararası terörizm. İstanbul: Nobel Yayincilik.

Chaliand, G. \& Blin, A. (2007). Zealots and assassins. (Ed.) Gérard Chaliand ve Arnaud Blin. The history of terrorism: from antiquity to Al Qaeda. (Translated by Edward Schneider, Kathryn Pulver ve Jesse Browner). Londra: University of California Press, 55-78.

Chaliand, G. \& Blin, A. (2007). The "golden age" of terrorism. (Ed.) Gérard Chaliand ve Arnaud Blin. The history of terrorism: from antiquity to Al Qaeda. (Translated by Edward Schneider, Kathryn Pulver ve Jesse Browner). Londra: University of California Press, 175-196.

Chaliand, G. \& Blin, A. (2007). From 1968 to radical Islam. (Ed.) Gérard Chaliand ve Arnaud Blin. The history of terrorism: from antiquity to Al Qaeda. (Translated by Edward Schneider, Kathryn Pulver ve Jesse Browner). Londra: University of California Press, 221-254.

Christian, P. (2019). Who were the Sicarii? Meridian Magazine. June 7, 2004. Retrieved from https://latterdaysaintmag.com/article-1-4364/ on June 1, 2019.

Cronin, A. K. (2010). Behind the curve: globalization and international terrorism. (Ed.) Michael E. Brown, Owen R. Cote, Sean M. Lynn-Jones ve Steven E. Miller. Contending with terrorism: roots, straegies, and responses. Londra: The MIT Press, 28-56.

Çağlar, A. (1997). Terör ve örgütlenme, TODAİE, 30(3), 119-133.

Dede, Ö. (2018). IŞID terör örgütünün türkiye'ye yönelik propaganda faaliyetleri ve yabancı teröristler. Unpublished master thesis, Gaziantep Üniversitesi Sosyal Bilimler Enstitüsü, Gaziantep.

Demir, C. K. (2008). Öğrenen örgütler ve terör örgütleri bağlamında PKK. Uluslararası İlişkiler Dergisi, 29, 57-88.

Goodman, M. (2008). Rome and Jerusalem: The clash of ancient civilizations. US: Vintage Books. 
Güler, R. T. \& Özdemir, Ö. B. (2018). DAEŞ: Ortaya çıkış1, yükselişi ve çöküşü. Ortadoğu'da devlet dışı silahlı aktörler: terör örgütleri, milisler, vekil güçler. (Ed.) Murat Yeşiltaş ve Burhanettin Duran. İstanbul: SETA Kitapları, 463-494.

Hoffman, B. (2006). Inside terrorism. New York: Columbia University Press.

Hürriyet. (2015). TSK sınır güvenliği tedbirlerinin bilançosunu çıkardı. Retrieved from http://www.hurriyet.com.tr/gundem/tsk-sinir-guvenligi-tedbirlerinin-bilancosunucikardi-40024240 on June 1, 2019.

Hürriyet. (2016). Türkiye, Brüksel saldırganını iki kez sınır dışı etmiş. Retrieved from http://www.hurriyet.com.tr/dunya/turkiye-bruksel-saldirganini-iki-kez-sinir-disietmis-40074994 on June 1, 2019.

İstanbullu, B. (2017). Suriye'deki Sünni muhalif grupların yabancı savaşçı temininde dinin etkisi ve propaganda aracı olarak Türkiye özelinde medya kullanımı örnekleri. Unpublished master thesis, İstanbul Üniversitesi Sosyal Bilimler Enstitüsü, İstanbul.

Kardaş, T. \& Özdemir, Ö. B. (2015). Avrupalı yabancı savaşçılar: kimlik, sosyal medya ve radikalleşme. SETA Analiz Raporu. No: 115.

Kartal, A. B. (2018). Uluslararası terörizmin değişen yapısı ve terör örgütlerinin sosyal medyayı kullanması: Suriye'de DAEŞ ve YPG örneği. Güvenlik Stratejileri, 14, 3977.

Kurum, M. (2015). Terörist örgütlerin güvenli ortamlarl ve terörist örgütler ile mücadelede güvenli ortamları hedef alma yaklaşımı: PKK terörist örgütü örneği. Unpublished Ph.D.Thesis, Kara Harp Okulu Savunma Bilimleri Enstitüsü, Ankara.

Laqueur, W. (1999). The new terrorism: Fanaticism and the arms of mass destruction. Oxford: Oxford University Press.

Lewis, B. (1967). The assassins: a radical sect of Islam. Oxford: Oxford University Press.

Lewis, J. D. (2013). Al Qaeda in Iraq resurgent: the breaking the walls campaign. Middle East Security Report. Retrived from http://www.understandingwar.org/sites/default/files/AQI-Resurgent-10Sept_0.pdf on June1, 2019.

Milliyet. (2016). Belçika'nın başkenti Brüksel'de art arda bombalı saldırı. Retrived from http://www.milliyet.com.tr/dunya/son-dakika-haberi-belcikanin-baskenti-brukseldeart-arda-bombali-saldiri-2213893 on June 1, 2019.

Ministry Of Interior. (2017). Türkiye'nin DEAŞ ile mücadelesi. Retrived from https://www.icisleri.gov.tr/kurumlar/icisleri.gov.tr/IcSite/strateji/deneme/YAYINLA R/\%C4\%B0\%C3\%87ER\%C4\%B0K/deas\%20en.pdf on June 1, 2019.

Özer, S. \& Kaykı, H. G. (2015). Türkiye’den ‘yabancı savaşçı’larla yoğun mücadele. Retrived from https://www.aa.com.tr/tr/turkiye/turkiyeden-yabanci-savascilarla-yogunmucadele/22968 on June 1, 2019. 
Özerkmen, N. (2004). Terör, terörzm ve radikal İslamcı terör. Ankara Üniversitesi Dil ve Tarih-Coğrafya Fakültesi Dergisi, 44(2), 247-265.

Rapoport, D. C. (2003). The four waves of rebel terror and september 11. (Ed.) Charles W. Kegley. The new global terrorism: characteristics, causes and controls. New Jersey: Prentice Hall, 36-52.

Taner, B. (2000). Terörizm ve turizm. Anatolia Turizm Araştırmaları Dergisi, 93-98.

Tavares, J. (2004). The open society assesses its enemies: shocks, disasters and terrorist attacks. Journal of Monetary Economics, 51(5), 1039- 1070.

Ternon, Y. T. (2007). Russian terrorism, 1878-1908. (Ed.) Gérard Chaliand ve Arnaud Blin. The history of terrorism: from antiquity to Al Qaeda. (Translated by Edward Schneider, Kathryn Pulver ve Jesse Browner). Londra: University of California Press, 132-174.

Thornton, T. P. (1964). Terror as a weapon of political agitation. Internal war: problems and approaches. (Ed. Harry Eckstein). New York: The Free Press, 71-79.

United Nations Security Council Resolution. (2014). The Islamic state in Iraq and the levant and the Al-Nusrah front for the people of the levant: report and recommendations submitted pursuant to resolution. Retrived from https://www.un.org/en/ga/search/view_doc.asp? symbol=S/2014/815 on June 1, 2019.

Urhal, Ö. (2009). Küreselleşen dünyada güvenlik (milli güvenlik, kamu güvenliği, örgütlü suçlar ve suç istihbaratı). Ankara: Adalet Yayınevi.

Wilkinson, P. (1986). Terrorism and the liberal state. Londra: Macmillan Press.

Yeşiltaş, M., Özdemir, Ö. B., Öncel, R., Düz, S. \& Öztürk, B. (2016). Sınırdaki düşman: Türkiye'nin DAİŞ ile mücadelesi. SETA Rapor. No: 65. İstanbul: Turkuvaz Haberleşme ve Yayıncılık. 